\title{
PENINGKATAN KAPASITAS KELEMBAGAAN DESA TANGGAP BENCANA
}

\author{
Yusuf Adam Hilman ${ }^{*}$, Khoirurrosyidin ${ }^{2}$, Robby Darwis Nasution ${ }^{3}$ \\ 1,2.3Program Studi Ilmu Pemerintahan, FISIP, Universitas Muhammadiyah Ponorogo \\ Email : adam_hilman@umpo.ac.id ${ }^{* 1}$, rosyidin.kh@gmail.com ${ }^{2}$, darwisnasution69@gmail.com ${ }^{3}$
}

\begin{abstract}
Abstrak
Praktik pemberdayaan yang dilakukan berangkat dari kondisi kelembagaan pemerintahan desa, yang masih mencari formula yang tepat dalam rangka memperkuat kapasitasnya dalam membangun sistem penanggulangan bencana di level pemerintah desa, supaya dapat memunculkan bentuk kelembagaan desa tangga bencana yang tepat. Penguatan kelembagaan desa tanggap bencana berusaha mengujikan permodelan dengan memperkuat kelembagaan desa, melalui beberapa tahapan, diantaranya: 1). Komunikasi dengan pemerintah desa 2). FGD dan musyawarah Permodelan desa tanggap bencana, 3). Rekomendasi hasil FGD dan Musyawarah. Pemerintah desa melihat bahwa kelembagaan desa tanggap bencana dirasakan sangat di perlukan, beberapa hal telah disepakati, terkait pembentukan kelembagaan Tangguh bencana, persoalan anggaran, dna juga partisipasi masyarakat, yang harus dilanjutkan dalam tahap selanjutnya.
\end{abstract}

Keyword: Kelembagaan; Pemerintahan Desa; Desa Tanggap Bencana;

\begin{abstract}
Empowerment practices depart from the institutional condition of village government, which is still looking for the right formula in order to strengthen its capacity in building disaster management systems at the village government level, in order to bring about the right form of village disaster ladder institutional. Strengthening the village's institutional disaster response seeks to test the modeling by strengthening village institutions, through several stages, including: 1). Communication with the village government 2). FGD and disaster response village modeling deliberations, 3). Recommendations of FGD and Deliberation results. Pemerintah desa sees that the village institutional disaster response is felt very much in need,several things have been agreed, related to the establishment of tangguh institutional disaster, budget issues, dna also community participation, which must be continued in the next stage.
\end{abstract}

Keyword: Institutional; Village Government; Disaster Response Village;

\section{PENDAHULUAN}

Letak Desa Ngabar Kecamatan Siman Kab.Ponorogo dengan Kec. Siman Kab. Ponorogo Kurang Lebih $5 \mathrm{Km}$ dengan waktu tempuh 15 Menit sedang dengan Pusat Pemerintah Kab. Ponorogo 7 Km kearah selatan dengan waktu tempuh 15 Menit. Dari Desa Ngabar Kecamatan Siman Kabupaten Ponorogo ke Propinsi Kurang lebih 207 Km. Desa Ngabar terletak diantara 2 sungai yaitu sungai keyang dan sungai gendol walaupun berada di antara 2 sungai setelah adanya normalisasi sungai tersebut Desa Ngabar bebas dari banjir, untuk itu kami ucapkan banyak terima kasih pada pemerintah kabupaten Ponorogo (Ngabar, 2020). 


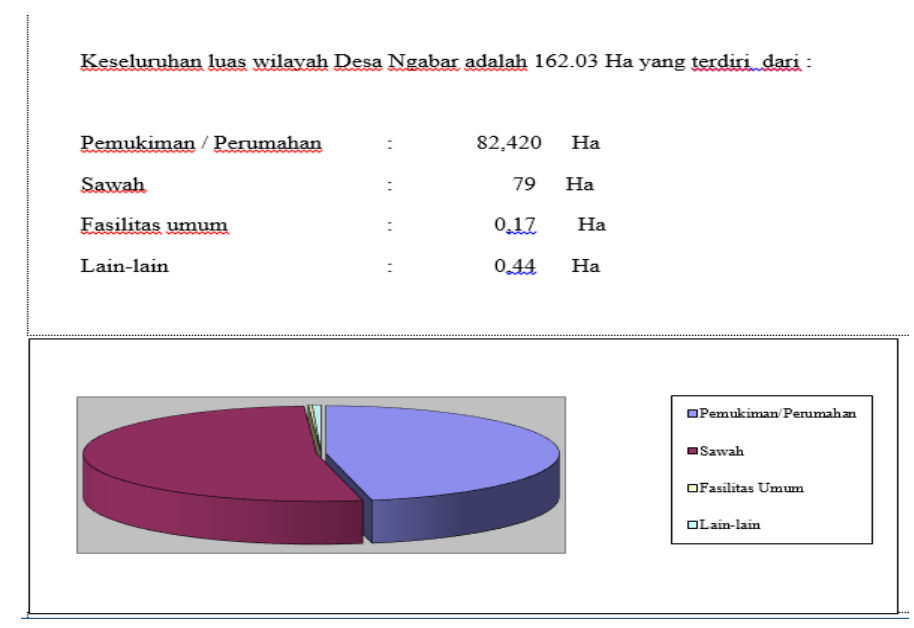

Gambar 1 Grafik Luas wilayah Desa Ngabar

Sumber diolah dari : (Ngabar, 2020)

Musim Penghujan di Bulan Februari menyebabkan beberapa wilayah yang ada di Kabupaten Ponorogo terkena banjir, salah satu kecamatan yang terdampak adalah kecamatan siman, wilayah Ngabar juga berpotensi terkena banjir, hal ini perlu disikapi oleh Pemerintahan Desa untuk mempersiapkan hal kejadian tersebut. Dia menyebutkan, air banjir menggenangi ratusan rumah warga dan lahan pertanian sejak Rabu (3/2/2021) malam, dan pada Kamis (4/2/2021) air yang sebelumnya mencapai ketinggian 50-60 cm, mulai surut sehingga warga bisa beraktivitas kembali (Subekhi, 2021).

Kesiapan secara kelembagaan terkait penanggulangan bencana di Desa Ngabar Kecamatan Siman, Kabupaten Ponorogo, masih sangat terbatas, selama ini upaya penanggulangan bencana masih sebatas penganggaran untuk bencana yang dimasukan dalam dokumen APBDes, sehingga belum efektif dan hanya bersifat pasif, sehingga di perlukan upaya secara sistemik dan berkelanjutan untuk melakukan manajemen kebencanaan di desa tersebut.

Pemerintah Desa Ngabar, Kecamatan Siman, Kabupaten Ngabar, memiliki keterbatasan dalam mencari bentuk kelembagaan desa tanggap bencana yang efektif, selama ini upaya penaggulangan bencana yang dilakukan desa, masih sebatas menyusun anggaran untuk bencana yang dimasukan dalam APBDes itupun bersifat pasif, anggaran baru bisa di realisasikan ketika terjadi bencana, sehingga tidak memiliki bentuk kelembagaan desa tanggap bencana yang terukur, sistematis, dan berkelanjutan. Padahal bencana tidak hanya persoalan administratif, 
melainkan multi aspek, dimana bencana harus di persiapkan dalam hal menejemen resiko yang akan di hadapai, sehingga perlu direncanakan, melalui pembentukan organisasi atau satuan tugas yang dapat dilatih secara profesional, sehingga lebih efektif karena melibatkan banyak pihak sehingga dapat melibatkan semua lapisan masyarakat yang ada di desa.

\section{METODE}

Penguatan kapasitas kelembagaan desa tanggap bencana melibatkan, Pemerintah Desa Ngabar, Kecamatan Siman, Kabupaten Ponorogo dan juga tim ahli penyusun desa tanggap bencana, selain itu praktik pengabdian ini juga melibatkan masyarakat dan komunitas yang ada di Desa. Program penguatan kapasitas kelembagaan desa tanggap bencana akan dilaksanakan dalam beberapa tahapan, antara lain:

1. Proses komunikasi tim pengabdi dengan steakholder Pemerintah Desa Ngabar, Kecamatan Siman Kabupaten Ponorogo.

2. Melakukan pemaparan permodelan desa tanggap bencana

3. Melakukan musyawarah dengan steakholder Pemerintah Desa Ngabar, Kecamatan Siman Kabupaten Ponorogo.

4. Pembuatan rekomendasi dari hasil musayawarah terkait permodelan desa tanggap bencana.

5. Tindaklanjut hasil rekomendasi oleh Pemerintah Desa Ngabar, Kecamatan Siman Kabupaten Ponorogo.

Pelaksanaan program dilakukan di Desa Ngabar, Kecamatan Siman, Kabupaten Ponorogo. Dimana pelaksana teknis adalah perangkat Desa Ngabar, masyarakat dan komunitas masyarakat dari tahap awal perumusan hingga pelaksanaan program.

Tahapan yang dilakukan akan diadakan evaluasi, untuk melihat sejauhmana efektifitas dari proses yang dilakukan, sehingga dapat benar - benar sesuai dengan harapan dari tim pengabdi, ketika proses yang dilakukan tidak sesuai maka tim pengabdi bisa melakukan treatment supaya tahapan tersebut bisa berjalan dengan optimal. 


\section{HASIL DAN PEMBAHASAN}

Proses komunikasi tim pengabdi dengan steakholder Pemerintah Desa Ngabar, Kecamatan Siman Kabupaten Ponorogo.

Tim pengabdi melakukan komunikasi secara intensif dengan pemerintahan Desa Ngabar, selain melakukan komunikasi secara dua arah, kami juga melakukan permohonan melalui surat resmi dengan nomor 460/IV.2/PM/2021, dalam surat tersebut kami mengabarkan bahwa kami bersama tim pengabdi yang terdiri dari: Yusuf Adam Hilman, Khoirurrosyidin, Robby Darwis Nasution, Zachrotun Nizah, dan Nurul Amsori, meminta izin untuk melakukan pengabdian masyarakat dan juga melakukan Focus Grub Discussion (FGD), kegiatan tersebut akan di lakukan dalam rentan waktu 01 Juli s/d 14 Juli 2021, untuk tempatnya kondisional dikarenakan dalam masa pandemic COVID-19, maka aka nada penyesuaian sesuai dengan protokol Kesehatan.

\section{Melakukan pemaparan permodelan desa tanggap bencana dan musyawarah dengan steakholder Pemerintah Desa Ngabar, Kecamatan Siman Kabupaten Ponorogo}

Tim Pengabdi melakukan Pemaparan permodelan desa tanggap bencana yang dilakukan di balai desa, dalam kegiatan tersebut dihadiri oleh Pemerintah desa dalam hal ini kepala desa beserta sekertaris dan juga perangkat desa, secara rinci kegiatan tersebut dihadiri oleh:

Tabel 1 Peserta FGD dan Musyawarah desa tanggap bencana

\begin{tabular}{|c|l|l|}
\hline No & \multicolumn{1}{|c|}{ Nama Peserta } & \multicolumn{1}{|c|}{ Jabatan } \\
\hline 1 & Soeran & Kepala Desa \\
\hline 2 & M Samsun & Sekertaris Desa \\
\hline 3 & Tarmuji & Kaur Keuangan \\
\hline 4 & Harnoto & Kamituwo \\
\hline 5 & Agus Romdhoni & Kasi Pemerintahan \\
\hline 6 & Subagyo & Kesra \\
\hline 7 & Marikun & Perdes \\
\hline 8 & Waryono & Kaur Pembangunan \\
\hline 9 & Agus Supriyadi & Kaur TU \\
\hline 10 & Lusiati Ambarsari & Bidan Desa \\
\hline
\end{tabular}




\begin{tabular}{|c|l|l|}
\hline 11 & Dwi Handayani & Perawat Desa \\
\hline
\end{tabular}

Sumber diolah dari: data pengabdian

Pelaksanaan FGD dan musyawarah yang melibatkan kalangan akademisi dan juga pemerintah desa serta komunitas masyarakat memperlihatkan adanya model Collaborative Government yang sangat dinamis, dimana semua pihak saling mengutarakan pendapat berdasarkan pengalamannya, dengan tujuan yang sama memperkuat kapasitas kelembagaan desa dalam penanggulangan bencana.

Gambar 1 Proses Musyawarah antara Pemerintah desa, akademisi dan komunitas masyarakat

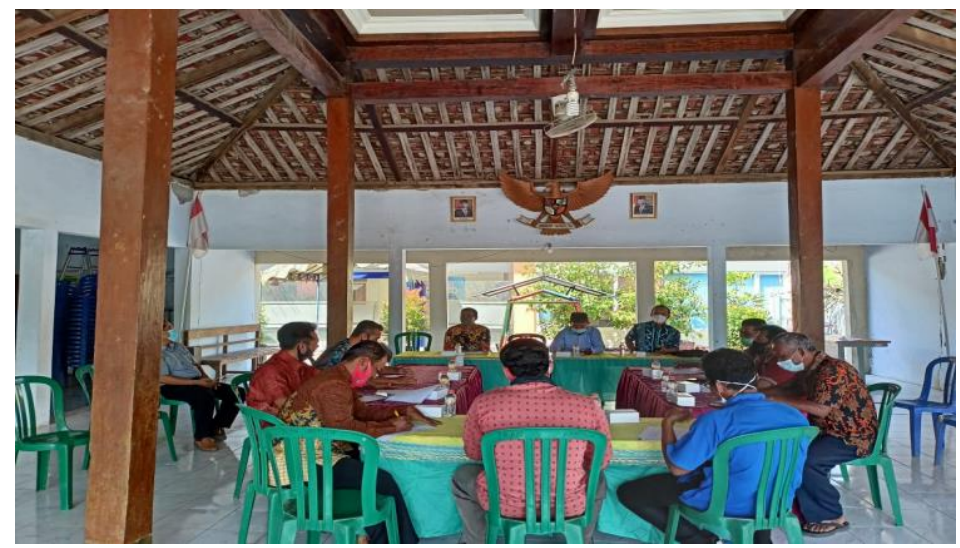

Sumber diolah dari: hasil dokumentasi pengabdian

Proses musyawarah dan pemaparan model desa tanggap bencana, dilakukan dengan protokol Kesehatan melibatkan sebanyak 15 orang peserta, yang mana 15 peserta tersebut terdiri dari unsur akademisi, pemerintah desa, dan juga komunitas masyarakat, ditambah media, sehingga terlihat FGD yang sangat dinamis, dan memunculkan beberapa rekomendasi penting, terkait pengembangan konsep Collaborative Government dalam rangka meningkatkan kapasitas desa Tangguh bencana.

\section{Pembuatan rekomendasi dari hasil musayawarah terkait permodelan desa tanggap bencana.}

Proses FGD dalampelaksanaanya, kemudian menghasilkan beberapa point penting, yang dapat kami himpun dari beberapa pendapat peserta, antara lain:

Menurut bapak Agus Romdhoni, dalam upaya memperkuat kapasitas penanggulangan bencana yaitu :1). Penguatan SDM bagi satgas diantaranya dengan mengadakan pelatihan - pelatihan. 2). Sarana dan prasarana penunjang 
yang memadai, 3).Pendanaan.

Menurut Bapak Turmuji, dalam kaitanya dalam peningkatan kapasitas desa tanggap bencana di perlukan pembentukan satgas bencana.

Menurut Bapak Mokamat Samsuri, dalam rnagka memperkuat kapasitas desa bencana, diperlukan pembentukan satuan tugas atau tim penanggulangan bencana, perlu adnaya penyusunan rencana sarana dan akomodasi penangulangan bencana, serta penyediaan anggaran penanggulangan bencana.

Menurut bapak Agus Supriyadi, terkait dnegan peningkatan kapasitas desa dlaam penanggulangan bencana perlu diadakan pelatihan - pelatihan terkait kebencanaan.

Menurut bapak Subagio, untuk meningkatkan kapasitas desa alangkah baiknya perlu dilakukan sosialisasi dan pelatihan yang menggandeng dinas terkait supaya dapat menyerap anggaran dan perlu dipikirkan darimana dan aitu di peroleh, selain itu perlu juga peningkatan kapasitas SDM satgas dan juga masyarakat terkait kebencanaan.

Menurut bapak Marikun, dalam upaya peningkatan kapasitas tersebut diperlukan upaya secara kelembagaan satuan tugas bencana yang baik, selain itu perlu ditingkatkan partisipasi masyarakat supaya desa siap menghadapi bencana.

Menurut bapak Harnoto, berkaitan dnegan peningkatan kapasitas desa, diperlukan upaya yang lebih agar partisipasi masyarakat lebih baik, dan juga diperlukan bantuan yang di perlukan untuk satuan tugas supaya kinerjanya lebih baik.

Menurut bapak Soeran, perlu adaya sebuah lembaga yang berkaitan erat dengan upaya tanggap bencana di desa ngabar.

Beberapa pendapat diatas, dapat diambil beberapa poin, terkait rekomendasi yang bisa dilakukan oleh Pemerintah Desa Ngabar, Kecamatan Siman Kabupaten Ponorogo, yaitu: 1). Perlunya pembuatan kelembagaan bencana berupa satuan tugas atau satgas kebencanaan, 2). Mempersiapkan sumber pendanaan dan sinkronisasi anggaran untuk pengembangan kelembagaan bencana, 3). Memperkuat partisipasi masyarakat dalam kegiatan kebencanaan. 


\section{KESIMPULAN}

Hasil kegiatan FGD dan pemaparan model desa tanggap bencana yang telah dilakukan, memperlihatkan adanya pemahaman yang sama dari pemerintah desa, komunitas masyarakat, jika kelembagaan kebencanaan di desa di perlukan, namun perlu disiapkan, beberapa hal, antara lain: 1). Penguatan kapasitas SDM bidang kebencanaan, 2). Integrasi dengan system penganggaran desa, untuk penguatan kelembagaan, 3). Perlu dilakukan upaya partisipasi dari masyarakat terkait kebencanaan, supaya desa dapat berdaya jika terjadi bencana.

Persoalan yang paling utama dalam proses penguatan kapasitas kelembagaan desa tanggap bencana adalah, soal sinkronisasi anggaran dan skala prioritas desa terhadap kelembagaan kebencanaan, sehingga perlu melibatkan banyak pihak untuk memperkuat tahapan selanjutnya dalam mewujudkan kelembagaan tanggap bencana di desa.

\section{UCAPAN TERIMA KASIH}

Kami mengucapkan terimakasih kepada Pemerintah Desa ngabar, Kecamatan SIman Kabupaten Ponorogo, dan tidak lupa kami haturkan terimakasih atas dukungan dari Universitas Muhammadiyah Ponorogo sehingga pengabdian ini bisa dilaksanakan.

\section{DAFTAR PUSTAKA}

Andriawan, A. H. (2020). Edukasi Tanggap Bencana Pada Masyarakat Di Desa Slahung Kabupaten Ponorogo. Society, 1(1), 48-58. doi:10.37802/society.v1i1.94

Lestari, Z. (2021). JARINGAN KOMUNIKASI AKSI CEPAT TANGGAP (ACT) DALAM PENANGANAN TANGGAP DARURAT PASCA BENCANA DI KOTA PALU. KINESIK, 7(3), 303-314. doi:10.22487/ejk.v7i3.133

Ngabar, P. D. (2020). Profile Desa. pONOROGO: Pemerintah Desa Ngabar.

Prasadi, O., Nurlinda Ayu Triwuri, Dwi Novia Prasetyanti, Eka Dyah Puspita Sari, \& Agus Santoso. (2020). PENERAPAN STANDAR CARA PRODUKSI PANGAN OLAHAN YANG BAIK (CPPOB) DI CILACAP. Jurnal Abdimas Bina Bangsa, 1(2), 215-222. doi:10.46306/jabb.v1i2.29

Subekhi, A. (2021, Februari 04). sindonews. Retrieved from https://daerah.sindonews.com/read/324038/704/banjir-bandang-terjang-ponorogo-1jembatan-hanyut-rumah-dan-sawah-tergenang-1612400538

Sukiyah, E., Aton, P., Zufialdi, Z., Devnita, R., Sudradjat, A., Haryanto, E. T., \& Purnomo, D. (2018). PEMBERDAYAAN MASYARAKAT DESA CISEWU BERBASIS POTENSI LOKAL DALAM MEWUJUDKAN MASYARAKAT TANGGAP BENCANA. Dharmakarya, 7(2). doi:10.24198/dharmakarya.v7i2.20128 